\title{
THE EFFECT OF VARIATION
} OF SAMPLE SOAKING TIMING AND CONCENTRATION OF HOMOGENIZING SOLVERS ON THE PRECENTAGE MORINGA

$$
\begin{gathered}
\text { LEAF PROTEIN (Moringa } \\
\text { oleifera) } \\
\text { by Pawito parwito }
\end{gathered}
$$

Submission date: 29-May-2020 02:22PM (UTC-0500)

Submission ID: 1295655220

File name: 6._Meirita.docx (78.54K)

Word count: 1633

Character count: 10697 


\title{
PENGARUH VARIASI WAKTU PERENDAMAN SAMPEL DAN JUMLAH PELARUT HOMOGENASI TERHADAP PERSENTASE EKSTRAK PROTEIN DAUN KELOR (Moringa oleifera)
}

\section{THE EFFECT OF VARIATION OF SAMPLE SOAKING TIMING AND CONCENTRATION OF HOMOGENIZING SOLVERS ON THE PRECENTAGE MORINGA LEAF PROTEIN (Moringa oleifera)}

\author{
Meirita Sari, Methatias Ayu Moulina \\ Program Studi Teknologi Hasil Pertanian, Universitas Dehasen Bengkulu \\ Email : meiritasari@unived.ac.id
}

\begin{abstract}
ABSTRAK
Penelitian ini merupakan salah satu bentuk pemanfaatan tumbuhan pangan, yaitu Kelor (Moringa oleifera). M. oleifera dapat tumbuh dengan baik di Provinsi Bengkulu. Pada bagian daun $M$. oleifera mengandung senyawa protein yang berperilaku seperti lektin. Senyawa ini dapat digunakan sebagai bahan antimikroba.Tahapan dalam penelitian ini meliputi ekstraksi protein daun $M$. oleifera dengan menggunakan metode salting in dan salting out. Penelitian ini bertujuan untuk mengetahui pengaruh waktu perendaman dan jumlah pelarut dalam proses ekstraksi tahap homogenasi terhadap persentase ektrsak protein. Hasil menunjukan waktu perendaman berpengaruh signifikan dibandingkan jumlah pelarut pada tahap homogenasi ektraksi protein daun kelor (Moringa oleifera). Semakin lama waktu yang dibutuhkan maka semakin besar Persentase ekstrak protein daun M. oleifera. Penelitian ini berguna bagi peneliti, masyarakat, bidang kesehatan, serta perkembangan ilmu pengetahuan maupun dunia pendidikan.
\end{abstract}

Kata Kunci: Moringa oleifera; Ekstraksi; Protein

\section{ABSTRACT}

This research is one form of utilization of food plants, namely Moringa (Moringa oleifera). M. oleifera can grow well in Bengkulu Province. The leaves of M. oleifera contain protein compounds that behave like lectins. This compound can be used as an antimicrobial material. The stages in this study include the extraction of $M$. oleifera leaf protein using salting in and salting out methods. This study aims to determine the effect of the immersion time and the amount of solvent in the homogenation stage extraction process on the percentage of protein extract. The results showed that the immersion time had a significant effect compared to the amount of solvent in the homogenation stage of Moringa oleifera leaf protein extraction. The longer the time needed, the greater the percentage of M. oleifera leaf protein extract. This research is useful for researchers, the public, the health sector, and the development of science and education.

Keywords: Moringa oleifera, Extraction, Protein

\section{PENDAHULUAN}

Kondisi geografis dan keadaan wilayah

propinsi Bengkulu yang subur memungkinkan banyaknya area hutan dengan keanekaragaman yang tinggi. Hal ini memberikan peluang besar untuk 
peneliti dalam mengembangkan potensi yang dimiliki oleh suatu tumbuhan. Pada tumbuhan terkandung senyawa metabolit sekunder dan metabolit primer yang memiliki aktivitas biologi. Beberapa senyawa metabolit primer antara lain karbohidrat, lemak dan protein. Terdapat tumbuhan perdu yang memiliki kandungan protein yang cukup tinggi yaitu kelor (Moringa oleifera). Kelor merupakan tumbuhan perdu dengan batang kayu yang mudah patah namun mempunyai akar yang kuat serta daun sebesar ujung jari, berbentuk bulat telur dan tersusun majemuk (Sari, 2017). Pemanfaatan daun kelor masih terbatas pada daun mudanya sebagai menu lauk pauk. Daun termasuk bagian tumbuhan yang padat nutrisi. Tepung dari daun kelor mengandung kadar protein sebesar $28,7 \%$ protein kasar/total (Teixeira, 2014).

Protein mempunyai peranan penting dalam aktivitas metabolisme tubuh manusia. Terdapat kelompok protein yang berinteraksi secara khas dengan karbohidrat spesifik yaitu lektin (lam, 2011). Dimana karbohidrat termasuk komponen utama pembentuk sel baik pada prokariot maupun eukariot. Ikatan yang terbentuk ini mengakibatkan perubahan permeabilitas membran sel. Membran sel berperan dalam menjaga komposisi ion-ion yang ada dalam 52 sitoplasma untuk berfungsinya suatu sel. Perubahan permeabilitas membran sel menyebabkan terganggunya proses transport nutrisi dan terhambatnya aktivitas serta biosintesis enzim-enzim spesifik yang diperlukan dalam reaksi metabolisme.

Hal ini mengakibatkan sel mengalami kekurangan nutrisi yang dibutuhkan dalam proses pertumbuhan yang lama-kelamaan menimbulkan lisis pada sel (Haryanto, 2014). Sifat biologis protein lektin ini berpotensi untuk diteliti lebih lanjut sebagai antimikroba. Penelitian ini bertujuan untuk mengetahui pengaruh waktu perendaman dan jumlah pelarut dalam proses ekstraktsi terhadap persentase ektrsak protein. Ekstraksi merupakan penyarian zat-zat berkhasiat atau zat-zat aktif dari bagian tumbuhan obat, hewan dan beberapa jenis ikan termasuk biota laut. Ekstraksi bahan alam dimaksudkan untuk menarik komponen kimia yang terdapat pada bahan alam. Ekstraksi ini didasarkan pada prinsip perpindahan massa komponen zat ke dalam pelarut, dimana perpindahan mulai terjadi pada lapisan antar muka kemudian berdifusi masuk ke dalam pelarut (Harbone, 1996).

\section{METODE PENELITIAN}

Ekstraksi Lektin Daun Kelor (Moringa oleifera) 
Sampel daun kelor (Moringa oleifera) yang telah dipilih dan bersih ditimbang dan Kemudian digiling hingga menjadi bubur serta dihomogenisasikan dalam larutan buffer tris $\mathrm{HCl} \mathrm{pH} 10$ (metode salting in) menggunakan 3 varian perbandingan sampel dan pelarut (2:1, 1:1, 1:2) dalam kondisi lingkungan dingin dengan 3 varian waktu perendaman yaitu 1 jam, 12 jam dan 24 jam. Homogenat disaring, cairan hasil saringan disentrifugasi dengan kecepatan $3500 \mathrm{rpm}$ selama 15 menit dengan $\mathrm{T}=$ $4^{\circ} \mathrm{C}$. Pellet Hasil sentrifugasi tahap pertama dibuang dan supernatan diambil. Supernatan dipresipitasi dengan ammonium sulfat jenuh $70 \%$ (metode salting out) dengan perbandingan jumlah 1:1. Kemudian dilakukan sentrifugasi tahap kedua dengan kecepatan $13.500 \mathrm{rpm}$ selama 30 menit dengan $\mathrm{T}=4^{\mathrm{O}} \mathrm{C}$. (Sari, 2015).

Penentuan konsentrasi lektin biji $A$. microcarpum

Penentuan konsentrasi protein dengan metode biuret menggunakan spektrofotometer PD 303S. Larutan sampel yang akan diukur konsentrasinya diberi perlakuan sebagai berikut: $0,5 \mathrm{~mL}$ sampel ditambahkan dengan $9,5 \mathrm{~mL}$ larutan biuret, divortex mixer, kemudian diletakkan pada penangas air (water bath) dengan suhu $40^{\circ} \mathrm{C}$ selama 10 menit. Setelah itu dilakukan pengukuran pada spektofotometer PD 303S dengan panjang gelombang $540 \mathrm{~nm}$.

\section{HASIL dan PEMBAHASAN}

\section{Ekstraksi lektin daun kelor (Moringa}

oleifera)

Tumbuhan yang diekstraksi proteinnya adalah tumbuhan Moringa oleifera tepatnya pada bagian daun. Sampel tersebut dihaluskan terlebih dahulu, guna memperluas permukaan bidang sentuh sampel sehingga peluang kontak antara sampel dengan pelarut semakin banyak dan mempermudah penetrasi pelarut ke dalam sampel sehingga hasil semakin sempurna. Selain itu juga dimaksudkan agar sel atau jaringan tumbuhan yang mengandung senyawa-senyawa organik dapat terlarut sebanyak mungkin dalam pelarut yang terbatas.

Sampel yang telah halus, dihomogenkan dengan buffer dingin Tris$\mathrm{HCl} \mathrm{pH}$ 10. Larutan buffer dengan $\mathrm{pH}$ yang lebih rendah dari 10 akan mengkibatkan depurifikasi dan mengakibatkan protein terdistribusi ke fase fenol selama proses deproteinisasi. Sedangkan $\mathrm{pH}$ larutan yang lebih tinggi dari 10 akan mengakibatkan pemisahan untaian protein. Fungsi larutan buffer 
adalah untuk menjaga struktur protein selama proses penghancuran dan purifikasi sehingga memudahkan dalam mencegah aktivitas enzim pendegradasi protein dan mencegah perubahan pada molekul protein.

Hasil homogenasi yang dinamakan homogenat umumnya masih berupa larutan keruh yang terdiri dari debris sel (bagian sel yang tidak hancur), organel-organel sel dan makromolekul penyusun sel diantaranya yaitu protein. Untuk memisahkan molekul dalam larutan ini yaitu menggunakan metode sentrifugasi. Tujuan dari sentrifugasi yaitu pemisahan larutan berdasarkan perbedaan berat molekulnya. Dengan sentrifugasi, debris dan organel sel akan mengendap di dasar tabung sentrifus (dinamakan pellet), sedangkan makromolekul (termasuk di dalamnya protein) yang ukurannya jauh lebih kecil daripada debris dan organel sel tidak akan mengendap tetapi terlarut dalam buffer (dinamakan supernatan yang bening). Supernatan inilah yang dipakai sebagai sampel untuk analisis isolasi protein. Hasil sentrifugasi tahap pertama dapat dilihat pada gambar 1 .

Supernatan hasil sentrifugasi pada tahap pertama perlu diendapkan kembali untuk mendapatkan ekstrak protein. Pengendapan dilakukan dengan menambahkan amonium sulfat $70 \%$. Presipitasi protein merupakan pengendapan yang terjadi karena penggumpalan yang parsial. Presipitasi disebabkan oleh berkurangnya kelarutan protein (perubahan fisik) yang terjadi karena perubahan kimia. Presipitasi disebabkan oleh pengembangan molekul protein akibat unfolding atau membukanya heliks-heliks protein. Presipitasi juga terjadi akibat terganggunya kesetabilan koloid yang disebabkan oleh menurunnya muatan elektrostatik protein sehingga gaya gravitasi akan lebih dominan dibandingkan gaya tolak-menolak antar molekul.

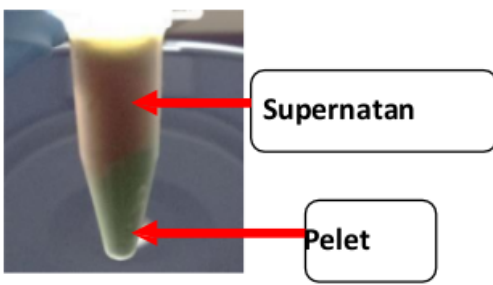

Gambar 1. Hasil Sentrifugasi tahap pertama 


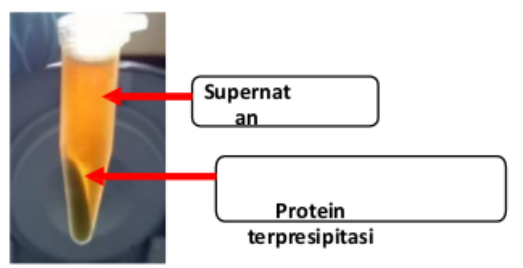

Gambar 2. Hasil sentrifugasi tahap kedua

\begin{abstract}
Supernatan yang dipresipitasi dengan ammonium sulfat $70 \%$ merupakan metode salting out. Mekanisme dasar salting out sangat kompleks yaitu pengendapan terjadi karena persaingan antara garam dan protein untuk mengikat air. Pada konsentrasi tinggi, kekuatan ionik garam semakin kuat sehingga garam lebih dapat mengikat molekul air. Dengan demikian, tidak cukup banyak air yang terikat pada protein sehingga gaya tarik menarik antar molekul protein lebih menonjol dibandingkan dengan tarik menarik antara air dan protein. Dalam kondisi seperti itu maka protein akan mengendap.

Pada isolasi lektin, untuk pemisahan protein dilakukan dua kali pengendapan melalui sentrifugasi. Sentrifugasi pertama pada $3500 \mathrm{rpm}$ selama 15 menit untuk memisahkan pengotor yang masih terdapat pada larutan sampel selanjutnya sentrifugasi kedua pada 13.500 rpm selama 30 menit untuk memisahkan protein terpresipitasi dengan larutannya (Englard, 1990),
\end{abstract}

\begin{abstract}
pelletnya diambil karena merupakan protein presipitasi, kemudian pellet tersebut dilakukan penentuan konsentrasi protein. Analisis kuantitatif protein hasil pengendapan amonium sulfat (jenis protein lebih spesifik) pada penelitian ini diperoleh rendemen terendah sebesar $2,44 \%$. Persentase ekstrak protein tertinggi yang diperoleh dari $305 g$ sampel biji $M$. oleifera adalah sebesar $21,897 \%$ atau $66,786 \mathrm{~g}$.
\end{abstract}

\section{Penentuan Konsentrasi Protein}

Protein hasil sentrifugasi homogenat masih terdiri dari berbagai jenis protein (atau dinamakan crude protein) ataupun protein hasil pengendapan amonium sulfat (jenis protein lebih spesifik) selanjutnya dapat dianalisis secara kuantitatif maupun kualitatif. Analisis kuantitatif protein pada penelitian ini menggunakan spektrofotometer PD 303S. dengan panjang gelombang $540 \mathrm{~nm}$. Dengan spektrofotometer dapat diketahui 
banyaknya atau jumlah protein dalam suatu sampel dan diperoleh konsentrasi $3000 \mathrm{mg} / \mathrm{L}$ pada sampel protein daun $M$. oleifera .

\section{KESIMPULAN}

Waktu perendaman berpengaruh signifikan dibandingkan jumlah pelarut pada tahap homogenasi ektraksi protein daun kelor (Moringa oleifera). Semakin lama waktu yang dibutuhkan maka semakin besar Persentase ekstrak protein daun M. oleifera.

\section{UCAPAN TERIMAKASIH}

Penulis mengucapkan terima kasih kepada Kemenristek Dikti, Ketua Prodi Pertanian Universitas Dehasen Bengkulu dan pengelola Laboratorium Fakultas Kedokteran Universitas Bengkulu atas bantuan dalam pelaksanaan penelitian ini.

\section{DAFTAR PUSTAKA}

Englard, S., S. Seifter. 1990. Precipitation Techniques. USA: Academic Press

Harborne, J. B. 1996. Metode Fitokimia. Bandung: Penerbit ITB

Haryanto, H., dan Muslim, C. 2014. Buku Ajar Membran Biologi; Struktur dan Fungsi. Yogyakarta: Deepublis

Lam, S.K., and Ng, T.B. 2011. Lectins: Production and practical applications. Appl Microbiol Biotechnol. 89:45-55

Sari, Meirita. 2015. Isolasi Lektin Biji Kabau (Archidendron microcarpum) Dan Uji Aktivitas Antibakteri Serta Implementasinya Sebagai Modul Pembelajaran Koba. Jurnal Pendipa. vol 2 no 3

Sari, Meirita. 2017. Koagulan Alami Dari Serbuk Biji Kelor (Moringa oleifera) Terhadap Limbah Cair Industri Tahu. Jurnal Agritepa. Vol. IV No.1

Teixeira EMB, Carvalho MRB, Neves VA, Silva MA, Arantes-Pereira LA. 2014. Chemical charactheristic and fractionation of proteins from Moringa oleifera Lam. leaves. Food Chemistry 147 51-54 
THE EFFECT OF VARIATION OF SAMPLE SOAKING TIMING AND CONCENTRATION OF HOMOGENIZING SOLVERS ON THE PRECENTAGE MORINGA LEAF PROTEIN (Moringa oleifera)

ORIGINALITY REPORT

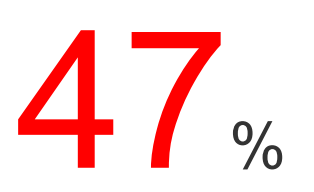

SIMILARITY INDEX

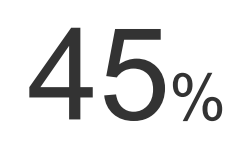

INTERNET SOURCES
$6 \%$

PUBLICATIONS
$14 \%$

STUDENT PAPERS

PRIMARY SOURCES

1 zombiedoc.com

Internet Source

2 mafiadoc.com

Internet Source

3 id.scribd.com

Internet Source

$5 \%$

4 www.scribd.com Internet Source

5 repository.ump.ac.id Internet Source

6 edoc.pub Internet Source 
9 documents.mx

Internet Source

10 Submitted to Sriwijaya University

Student Paper

$1 \%$

11 journal.ipb.ac.id

Internet Source

12 es.scribd.com

Internet Source

13 sinta3.ristekdikti.go.id

Internet Source

14 peripi.org

Internet Source

$1 \%$

15 Submitted to Universitas Diponegoro

Student Paper

$1 \%$

16 Supriyanto Supriyanto. "Pengaruh Metode

Latihan Plyometric dan Latihan Beban dengan

Kecepatan Reaksi terhadap Power Otot Tungkai

Pemain Bolavoli Putra", Gelanggang Olahraga:

Jurnal Pendidikan Jasmani dan Olahraga

(JPJO), 2018

Publication 
On 